\title{
Cambial activity of Populus tremula $\times$ Populus alba clone 717-1B4 in hydroponic culture
}

\author{
Domenico Morabito, Aurore Caruso, Sabine Carpin, Cédric Carli, \\ Françoise Laurans, Christiane Depierreux, Guy Kahlem, and Philippe Label
}

\begin{abstract}
Populus tremula Michx. $\times$ Populus alba L. clone $717-1 \mathrm{~B} 4$ plants were grown in a hydroponic system in an effort to detect cambial activity in a changing nutrient environment. The secondary growth of the stem was determined by automated measurement of radial growth, as well as by histological study. This is the first time poplar cambial activity has been recorded in a hydroponic system. Further, we demonstrate that nutrient limitations can be tested with progressive deprivation of liquid medium. The system lends itself to measurements of stomatal conductance, primary stem growth, leaf growth, and radial stem growth. In this study we found that primary and secondary growth were affected by nutrient solution limitations. This hydroponic system will be valuable in elucidating the impact of environmental, physiological, and molecular factors on cambial activity and wood formation.
\end{abstract}

Résumé : Des plants de Populus tremula Michx. × Populus alba L. clone 717-1B4 ont été cultivés en système de culture hydroponique pour obtenir une activité cambiale dans un milieu nutritif variable. La croissance secondaire de la tige a été caractérisée par une mesure automatique de la croissance radiale et des observations histologiques. Les résultats montrent le premier enregistrement de l'activité cambiale en hydroponie chez le peuplier. En outre, nous démontrons que les carences nutritives peuvent être étudiées en privant progressivement les plants de solution nutritive. Le système se prête à la mesure de la conductance stomatique, de la croissance primaire de la tige, de la croissance foliaire et de la croissance radiale. Dans cette étude nous observons que les croissances primaire et secondaire sont touchées par les carences nutritives. Ce système de culture en hydroponie est exploitable pour l'élucidation de l'impact des facteurs environnementaux, physiologiques et moléculaires sur l'activité cambiale et la formation du bois.

\section{Introduction}

Poplars are among the fastest growing trees in temperate latitudes and produce a wood widely used by the forest industry (Dickmann et al. 1983). One of the major aims of a poplar breeding program is to introduce selected trees that will increase the wood productivity of managed plantations. Wood production results from cambial activity in the stem (Larson 1994). To understand how cambial activity affects wood productivity, it is essential to control the effect of environmental factors. Growth of poplar in the field or even in pots does not allow precise control of the nutritional parameters, and in vitro culture of woody plants has so far not led to wood formation. Moreover, sampling of growing tissue is limited in soil because of the concomitant wounding effect, which decreases the quality of samples for molecular biology analyses. Taking into account these criteria, we have de-

Received 7 September 2005. Accepted 28 November 2005. Published on the NRC Research Press Web site at http://cjfr.nrc.ca on 18 March 2006.

D. Morabito, A. Caruso, C. Depierreux, G. Kahlem, and S. Carpin. Laboratoire de biologie des ligneux et des grandes cultures, UFR - Faculté des sciences, Université d'Orléans, UPRES EA, 1207 rue de Chartres, B.P. 6759, 45067 Orléans CEDEX 2, France.

C. Carli, F. Laurans, and P. Label. ${ }^{\mathbf{1}}$ Institut national de la recherche agronomique, 2163 avenue de la Pomme de Pin, B.P. 20619 Ardon, 45166 Olivet CEDEX, France.

${ }^{1}$ Corresponding author (e-mail: philippe.label@orleans.inra.fr). veloped an hydroponic culture method to monitor cambial activity in poplar and to ease tissue sampling (Raynal et al. 1985; Robertson et al. 1994; Dubos et al. 2003). As an example, we have studied the effect of progressive reduction of nutrient solution on cambial activity. This treatment mimics the reduction of water availability and nutrient absorption observed under natural conditions (Wimmer et al. 2002). It is well known that secondary growth is widely affected by water availability during the growing season (Zahner 1968; Kramer et al. 1995; Ortuno et al. 2004). Such an effect has been observed in Picea glauca (Moench) Voss (Barber et al. 2000) and Thuja occidentalis L. (Tardif et al. 2001) and is interpreted as being an adaptive response to drought (Chen et al. 1997).

The aim of this study was to obtain secondary growth under hydroponically controlled conditions and to demonstrate that a limiting the nutrient solution affects secondary growth. The hybrid poplar clone 717-1B4 was chosen because of its rapid growth and its use as a model species (Bradshaw et al. 2000).

\section{Material and methods}

\section{Hydroponic culture conditions}

\section{Plant preparation}

Clone 717-1B4 of Populus tremula Michx. $\times$ Populus alba L., obtained at the Institut national de la recherche agronomique - Orléans, was used for hydroponic culture. Nodal segments, $15 \mathrm{~cm}$ long and with $11 \pm 1 \mathrm{~mm}$ diameter and one axillary bud, were treated for $30 \mathrm{~min}$ with indole-3butyric acid $\left(1.2 \mathrm{~g} \cdot \mathrm{L}^{-1}\right)$ and rooted in sand. After 1 month, 
48 rooted plants with a newly developed stem about $10 \mathrm{~cm}$ high and bearing 10 leaves were transferred to the hydroponic system (Kruse et al. 2003). Rooted cuttings were acclimated under hydroponic conditions for 15 days before the experiment as follows.

\section{Standard culture}

Plastic containers with 12 plants each were filled with 20 L of half-strength Murashige and Skoog culture medium (Murashige et al. 1962). A fish-tank pump provided aeration. Trees were grown in a growth chamber under environmentally controlled conditions: temperature was $21 \pm 1{ }^{\circ} \mathrm{C}$, relative water humidity was $75 \% \pm 5 \%$, and irradiance was $134 \mu \mathrm{mol} \cdot \mathrm{m}^{-2} \cdot \mathrm{s}^{-1}$ for $16 \mathrm{~h} \cdot \mathrm{day}^{-1}$.

\section{Treatments}

Day 0 is defined as the onset of radial growth measurement. Stress was applied at day 19 of the experiment.

\section{Control conditions}

The nutrient solution was refilled daily to the initial volume. Each week the solution was replaced with fresh solution. Twenty-four plants were cultured under control conditions throughout the experiment (39 days).

\section{Nutrient solution limitation}

During growth, leaf transpiration led to the decrease of nutrient solution in the tank. At day 19, we stopped daily replacement of the nutrient solution, thus imposing a gradient of water and nutrient limitation. This treatment was designated by "stress". Twenty-four plants were stressed for 20 days.

\section{Water status measurement}

We used a Scholander pressure chamber (Scholander et al. $1965)$ to measure predawn leaf water potential $\left(\Psi_{w p}\right)$. The leaf relative water content (RWC) was calculated as follows:

$$
\operatorname{RWC}(\%)=\frac{[(\text { fresh mass }- \text { dry mass }) \times 100]}{(\text { saturated mass }- \text { dry mass })}
$$

The stem water content (WS) was calculated as follows:

$$
\mathrm{WC}(\%)=\frac{[(\text { fresh mass }- \text { dry mass }) \times 100]}{\text { fresh mass }}
$$

Stomatal conductance $(g)$ was determined on both sides of poplar leaves with a steady state porometer (PMR-3, PP Systems, Hitchin, Hertfordshire, UK). Measurements were calculated as $g_{\text {abaxial }}+g_{\text {adaxial }}$ on a mature leaf (sixth leaf from the top of the plant).

\section{Primary and secondary growth measurement}

We determined leaf area increase $\left(\mathrm{cm}^{2} \cdot \mathrm{day}^{-1}\right)$ on 16 plants by using a binomial relationship between leaf maximum width and leaf area (Brignolas et al. 2000), with parameterization adapted to clone characteristics. The correlation was performed on 270 leaves collected from 10 different cuttings. We calculated the leaf area by drawing the leaf contour on a paper sheet $\left(80 \mathrm{~g} \cdot \mathrm{m}^{-2}\right)$, cutting out the form of the leaf, and weighing the paper. Each leaf width was manually measured. The formula used was

$$
L_{\mathrm{a}}=\left(0.71 \times L_{\mathrm{w}}^{2}\right)+\left(1.114 \times L_{\mathrm{w}}\right)
$$

Fig. 1. Radial growth measured with a linear motion sensor on the stem of Populus tremula $\times$ Populus alba clone 717-1B4 cultivated under hydroponic conditions.

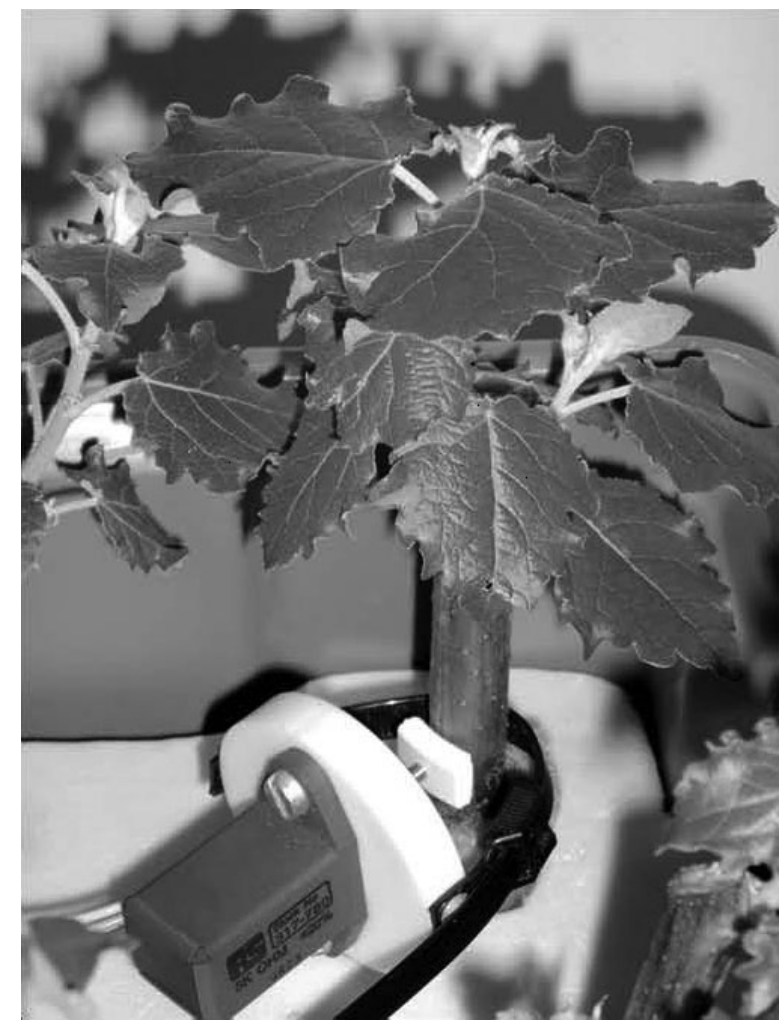

where $L_{\mathrm{a}}$ is leaf area $\left(\mathrm{cm}^{2}\right)$ and $L_{\mathrm{w}}$ is leaf width $(\mathrm{cm})$. The correlation coefficient was 0.98. Stem primary growth $\left(\mathrm{cm} \cdot \mathrm{day}^{-1}\right)$ was estimated for 16 plants per treatment by measuring the length of the axillary stem.

Radial growth was measured every 15 min for 39 days with an automatic point dendrometer on eight plants per treatment (Fig. 1). A linear motion sensor (AB Electronics Ltd., Romford, Essex, UK) was adjusted on the tree nodal segment so that the increasing stem diameter mechanically impinged on it, forcing the electric tension out of the variable resistance of the sensor connected as a tension divider. The variable tension was digitized by an analog-to-digital converter (Adlink Technology Inc., Taiwan) plugged into a PC-based recording data system. The software piloting this device and storing the collected data was developed in Visual Basic for Applications and integrated in Excel's spreadsheet (Microsoft, Redmond, Washington, USA). It is available from the authors upon request.

\section{Histological description}

For the observation of the cambial zone, stem pieces below the radial growth sensor were collected at day 0 and day 39 on four different cuttings and stored in $70(v / v)$ ethanol for 10 days at room temperature. Freehand sections were obtained with a razor blade and destained in $2.5 \%(\mathrm{~m} / \mathrm{v}) \mathrm{NaClO}$ aqueous solution for $6 \mathrm{~min}$. Sections were abundantly rinsed with distilled water, partially dehydrated in $25 \%(v / v)$ and $50 \%(v / v)$ aqueous ethanol for 2 min each, stained with $1 \%$ $(\mathrm{m} / \mathrm{v})$ aqueous Safranin $\mathrm{O}$ for $3 \mathrm{~min}$, subsequently stained 
Table 1. Predawn leaf water potential, leaf relative water content, and stem water content of Populus tremula $\times$ Populus alba clone 717-1B4 cultivated in hydroponic conditions and submitted to control or nutrient solution limitation.

\begin{tabular}{lllll}
\hline & & Day 19 & Day 30 & Day 39 \\
\hline Predawn leaf $\Psi_{\text {wo }}(\mathrm{MPa})$ & Control & $-0.45 \pm 0.01$ & $-0.43 \pm 0.04$ & $-0.47 \pm 0.04$ \\
& Stress & - & $-0.78 \pm 0.02^{*}$ & $-1.77 \pm 0.10^{*}$ \\
Leaf RWC $(\%)$ & Control & $81.1 \pm 7.9$ & $82.9 \pm 2.1$ & $80.0 \pm 3.1$ \\
& Stress & - & $72.8 \pm 5.3^{*}$ & $66.5 \pm 3.5^{*}$ \\
Stem water content $(\%)$ & Control & $67.6 \pm 2.2$ & $66.1 \pm 1.0$ & $62.5 \pm 2.4$ \\
& Stress & - & $65.3 \pm 3.5$ & $57.3 \pm 1.8^{*}$ \\
\hline
\end{tabular}

Note: Day 19 corresponds to the beginning of the stress period. *, significantly different at $P \leq 0.05(n=8)$.

Fig. 2. Time course of stomatal conductance of Populus tremula $\times$ Populus alba clone 717-1B4 cultivated under hydroponic conditions and submitted to control conditions $(\square)$ or nutrient solution limitation ( $\boldsymbol{\square})$. Day 19 corresponds to the beginning of the stress period. Vertical bars represent standard errors. Means for control and stressed cuttings $(n=16)$ were compared; asterisks indicate significant differences at $P=0.05$.

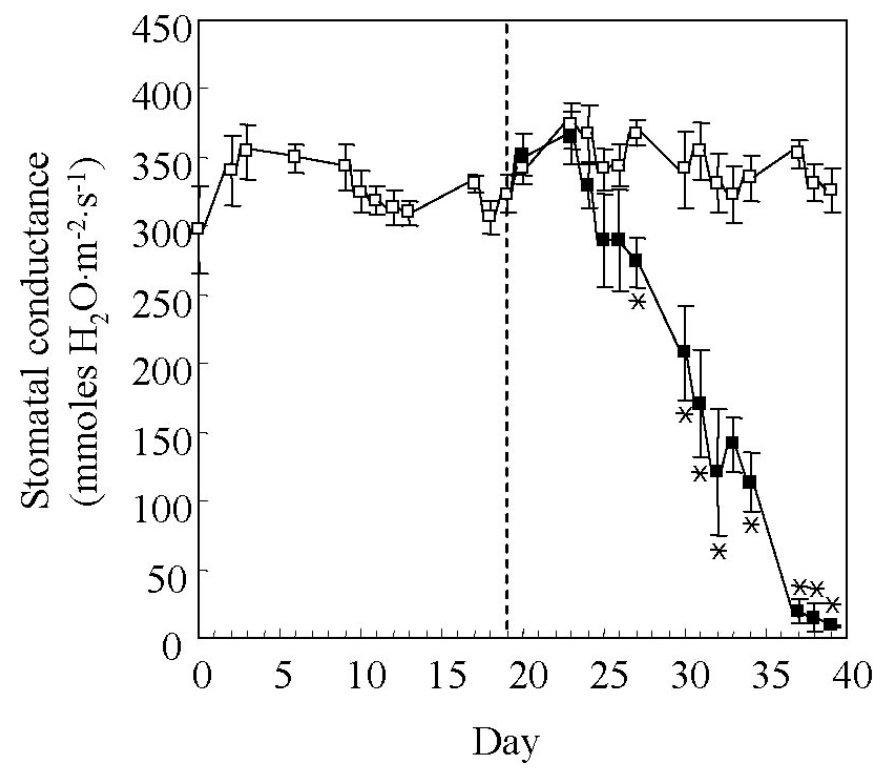

with $1 \%(\mathrm{~m} / \mathrm{v})$ aqueous Astra Blue at room temperature for 5 min (Srebotnik et al. 1994), and rinsed in absolute ethanol.

\section{Statistical methods}

Means for control and stressed treatments were compared by using Statview software version 5.0.1 (SAS Institute Inc., Cary, North Carolina, USA). In each case the number of replicates $(n)$ is indicated and the level of confidence defined at $P=0.05$.

\section{Results}

\section{Water status}

Predawn leaf $\Psi_{\mathrm{wp}}$, leaf RWC, and stem WC (Table 1) of control plants were $-0.45 \mathrm{MPa}, 81.1 \%$, and $67.6 \%$, respectively. These values did not vary significantly during the experiment. For the stressed plants, predawn leaf $\Psi_{\text {wp }}$ decreased to -0.78 and $-1.77 \mathrm{MPa}$ after 11 days (day 30) and 20 days (day 39), respectively. Leaf RWC significantly decreased to $72.8 \%$ and $66.5 \%$ after 11 days (day 30) and 20 days (day 39)
Fig. 3. Time course of stem length increase (A) and leaf area increase (B) of Populus tremula $\times$ Populus alba clone 717-1B4 cultivated in hydroponic conditions and submitted to control conditions $(\square)$ or nutrient solution limitation ( $\square$ ). Day 19 corresponds to the beginning of the stress period. Vertical bars represent standard errors. Means for control and stressed cuttings $(n=16)$ were compared; asterisks indicate significant differences at $P=0.05$.

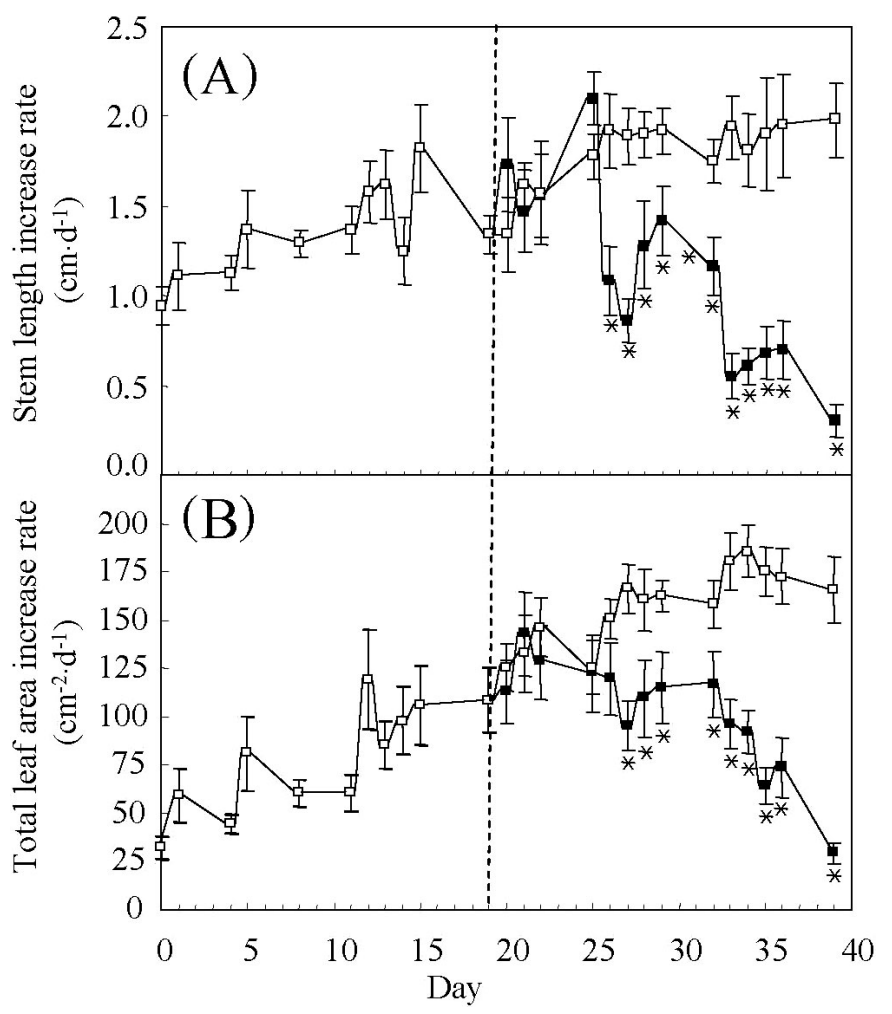

of nutrient solution deprivation, respectively. This stress significantly affected stem WC only by day 39 , when it reached $57.3 \%$ (Table 1). Stomatal conductance of the control plants remained stable at $300-370 \mathrm{mmol} \mathrm{H}_{2} \mathrm{O} \cdot \mathrm{m}^{-2} \cdot \mathrm{s}^{-1}$ throughout the experiment (Fig. 2). For stressed plants, stomatal conductance was not significantly affected before day 27 (8 days of stress). From day 27 to day 39, the stomatal conductance of stressed cuttings decreased to $10 \mathrm{mmol} \mathrm{H}_{2} \mathrm{O} \cdot \mathrm{m}^{-2} \cdot \mathrm{s}^{-1}$.

\section{Primary growth}

From day 0 until day 39 the stem length increase rate (designated by "stem growth") of control poplar cuttings 
Fig. 4. Time course of radial growth increase of Populus tremula $\times$ Populus alba clone 717-1B4 cultivated in hydroponic conditions and submitted to control conditions $(\square)$ or nutrient solution limitation ( $\square$ ). Day 19 corresponds to the beginning of the stress period. Vertical bars represent standard errors. Means for control and stressed cuttings $(n=16)$ were compared; asterisks indicate significant differences at $P=0.05$.

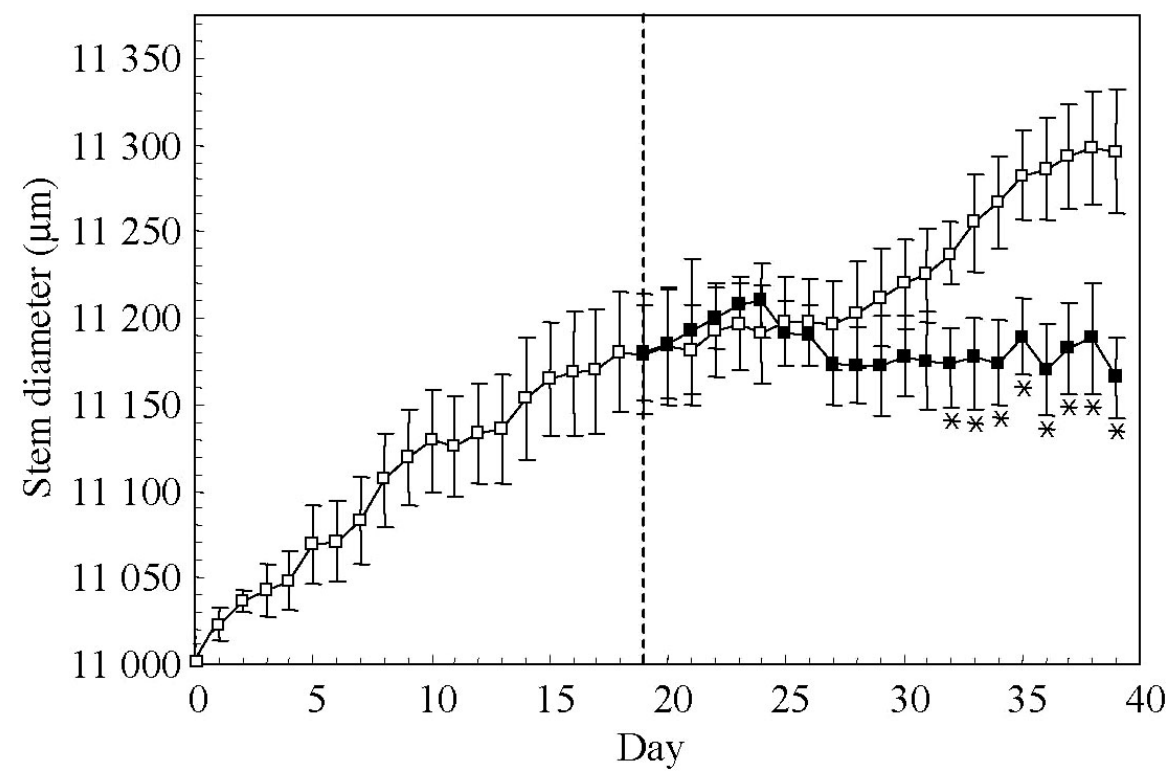

approximately doubled (Fig. 3A), to $1.99 \mathrm{~cm} \cdot \mathrm{day}^{-1}$ from $0.94 \mathrm{~cm} \cdot \mathrm{day}^{-1}$. During the same period, the total leaf area increase rate (designated by "leaf growth") of control plants increased to $183 \mathrm{~cm}^{2} \cdot \mathrm{day}^{-1}$, about six times the original value $\left(29 \mathrm{~cm}^{2} \cdot \mathrm{day}^{-1}\right)$ (Fig. 3B). Before we applied stress, stem growth increased to $1.36 \mathrm{~cm} \cdot$ day $^{-1}$ from $0.94 \mathrm{~cm} \cdot \mathrm{day}^{-1}$, and leaf growth increased to $120 \mathrm{~cm}^{2} \cdot \mathrm{day}^{-1}$ from $29 \mathrm{~cm}^{2} \cdot \mathrm{day}^{-1}$. Between day 19 and day 25, stem growth and leaf growth did not significantly differ between control and stressed plants. After day 26 stem growth decreased significantly in stressed plants to $0.3 \mathrm{~cm} \cdot \mathrm{day}^{-1}$ from $1.09 \mathrm{~cm} \cdot \mathrm{day}^{-1}$, and leaf growth decreased to $31 \mathrm{~cm}^{2} \cdot$ day $^{-1}$ from $132 \mathrm{~cm}^{2} \cdot$ day $^{-1}$. At the end of the stress treatment (day 39), stem growth and leaf growth were, respectively, eight and six times lower in stressed plants than in control plants.

\section{Secondary growth}

For control conditions, stem diameter increased at a steady rate of $7.5 \mu \mathrm{m} \cdot \mathrm{day}^{-1}$ (Fig. 4) to $11298 \mu \mathrm{m}$ from $11002 \mu \mathrm{m}$. Between the start of the experiment and the onset of stress (day 19), stem diameter increased to $11178 \mu \mathrm{m}$. from $11002 \mu \mathrm{m}$. During the period of stress, no differences were observed between control and stressed cuttings until day 31 (corresponding to 12 days of stress). After day 31, the stem diameter of control plants increased to $11298 \mu \mathrm{m}$ from $11196 \mu \mathrm{m}$, whereas that of stressed plants never exceeded on average $11189 \mu \mathrm{m}$ until the end of the experiment.

\section{Histology}

Tissue anatomy was observed at the onset of the culture (day 0) and at day 39 (Fig. 5). Cambial cells (CZ) could be observed at day 0 (Fig. 5B) between phloem (P) and xylem formed before the experiment (Xf), without any new xylem formed yet. In control plants (Fig. 5A), cambium was composed of at least two times more cells, and the xylem produced during the experiment $(\mathrm{Xc})$ showed the largest increment. A lowered production of xylem (Xs) occurred under stressed conditions (Fig. 5C). Under control conditions (Fig. 5A), the xylem increment was estimated to be $360 \mu \mathrm{m}$ during the 39 days of experiment, whereas only $175 \mu \mathrm{m}$ of xylem was produced at the same time in stressed plants.

\section{Discussion}

\section{Characterization of water stress}

In Populus euramericana (Dole) Guinier, growing in soil and submitted to 11 days of water withholding (Caruso et al. 2002), the decrease in predawn leaf $\Psi_{\text {wp }}$ was associated with stomatal closure and the decrease in leaf RWC. In $P$. tremula $\times P$. alba clone 717-1B4 cultivated under hydroponic conditions, we obtained the same results after 20 days of stress (Table 1), when approximately two-thirds of the root system was no longer in contact with the nutritive liquid medium (data not shown). Such results have also been observed in leaves of Lotus corniculatus L. stressed by water shortage in hydroponic culture. This drought was obtained by totally withdrawing the nutrient solution in contact with the roots for $8 \mathrm{~h}$ (Borsani et al. 2001). Under hydroponic conditions, leaf RWC measured under progressive nutrient solution deprivation (Table 1) was affected before stem WC was. From these measurements, we can estimate a maximum delay of 9 days between primary and secondary growth impacts of nutrient solution deprivation.

\section{Radial growth}

Under control conditions, we observed an increase in the radial diameter of the cuttings as a result of the cambial activity. The xylem width increment measured on tissue sections corresponded to the radial enlargement measured by the point dendrometer. Indeed, the histological study con- 
Fig. 5. Anatomical characterization of secondary growth on Populus tremula $\times$ Populus alba clone 717-1B4 cultivated in hydroponic conditions and submitted to control conditions or nutrient solution limitation. (A) Full secondary growth of control plant at day 39. (B) Initial observation of cambial zone before secondary growth (day 0). (C) Full secondary growth of stressed plant at day 39. CZ, cambial zone; P, phloem; Xf, final wood of the former xylem; Xc, control xylem increment; Xs, xylem increment during nutrient solution limitation. Bar represents $50 \mu \mathrm{m}$. Double arrowheads show tissue limits on the section. Lines between pictures show the xylem growth increment estimated for the section.
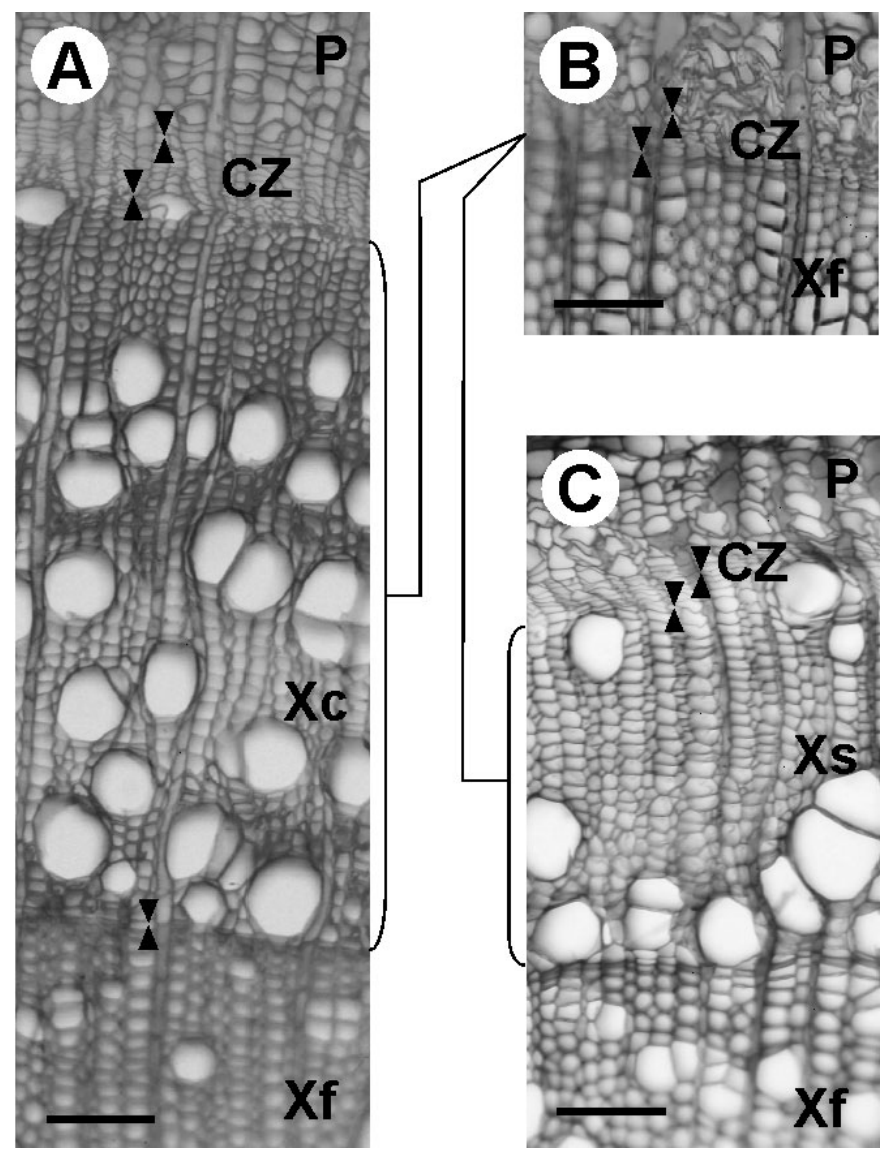

firmed that this diameter increase was mainly caused by the production of the xylem. The rate of phloem tissue production by the cambium is about $10 \%$ of the xylem production rate for most species (Larson 1994). Under hydroponic conditions, the stem diameter measurement showed that cambial growth was significantly arrested 12 days after the limitation of nutrient solution began.

\section{Relationship between nutrient solution limitation and radial growth}

Stomatal conductance decreases with increasing water stress (Comstock 2002). We observed the cessation of radial growth when stomatal conductance was $<110 \mathrm{mmol} \mathrm{H}_{2} \mathrm{O} \cdot \mathrm{m}^{-2} \mathrm{~s}^{-1}$. Plant responses to water withholding can be interpreted as being the result of progressive root desiccation (Davies et al. 1994), obtained in our case by withholding nutrient solution. Vascular cambium activity slowdown, impacting xylem pro- duction, has been shown to be a consequence of water deficit (Zahner et al. 1964; Rozenberg et al. 2002). From our results, stomatal conductance was reduced 8 days after water shortage began, whereas radial growth was significantly arrested 12 days after water shortage began. Therefore, we measured a 5-day delay between primary and secondary growth retardation. Histological observations confirmed the cambial activity slowdown: fewer xylem cells were produced under nutrient solution limitation than under control conditions. The observed 5-day delay could be interpreted as the time required for poplar cuttings cultured hydroponically to adjust their cambium activity to water shortage.

To our knowledge, this is the first report of cambial activity in hydroponic culture. This paper also emphasizes the observation of water-stress-like response at the cambial level in rooted cuttings cultured under hydroponic conditions. This system, in which the level of nutrient solution can be decreased more or less rapidly, could be used in the future to detect the adaptative and non-adaptative drought responses in cambial tissue involved in wood formation under limited water availability. This ability to control cambial activity by water availability or nutrient changes (heavy metals, salts) under hydroponic conditions makes this system a good model for studying cambial activity and wood formation.

\section{Acknowledgements}

The technical collaboration of Alain Guichard and Gilles Moreau is gratefully acknowledged. Both anonymous reviewers are deeply thanked for their help in improving the manuscript.

\section{References}

Barber, V.A., Juday, G.P., and Finney, B.P. 2000. Reduced growth of Alaskan white spruce in the twentieth century from temperature-induced drought stress. Nature (London), 405: 668-673.

Borsani, O., Diaz, P., Agius, M.F., Valpuesta, V., and Monza, J. 2001. Water stress generates an oxidative stress through the induction of a specific $\mathrm{Cu} / \mathrm{Zn}$ superoxide dismutase in Lotus corniculatus leaves. Plant Sci. 161: 757-763.

Bradshaw, H.D.J., Ceulemans, R., Davis, J., and Stettler, R. 2000. Emerging model systems in plant biology: poplar (Populus) as a model forest tree. J. Plant Growth Regul. 19: 306-313.

Brignolas, F., Thierry, C., Guerrier, G., and Boudouresque, E. 2000. Compared water deficit response of two Populus xeuramericana clones, Luisa Avanzo and Dorskamp. Ann. For. Sci. 57: 261266.

Caruso, A., Morabito, D., Delmotte, F., Kahlem, G., and Carpin, S. 2002. Dehydrin induction during drought and osmotic stress in Populus. Plant Physiol. Biochem. 40: 1033-1042.

Chen, S., Wang, S., Altman, A., and Hüttermann, A. 1997. Genotypic variation in drought tolerance of poplar in relation to abscisic acid. Tree Physiol. 17: 797-803.

Comstock, J.P. 2002. Hydraulic and chemical signalling in the control of stomatal conductance and transpiration. J. Exp. Bot. 53: 195-200.

Davies, W.J., Tardieu, F., and Trejo, C.L. 1994. How do chemical signals work in plants that grow in drying soil? Plant Physiol. 104: 309-314. 
Dickmann, D.I., and Stuart, K.W. 1983. The culture of poplars in eastern North America. Michigan State University Press, East Lansing, Mich.

Dubos, C., Le Provost, G., Pot, D., Salin, F., Lalane, C., Madur, D., Frigerio, J.M., and Plomion, C. 2003. Identification and characterization of water-stress-responsive genes in hydroponically grown maritime pine (Pinus pinaster) seedlings. Tree Physiol. 23: $169-179$.

Kramer, P.J., and Boyer, J.S. 1995. Water relations of plants and soils. Academic Press, San Diego, Calif.

Kruse, J., Hetzger, I., Mai, C., Polle, A., and Rennenberg, H. 2003. Elevated $p \mathrm{CO}_{2}$ affects $\mathrm{N}$-metabolism of young poplar plants (Populus tremula $\times P$. alba) differently at deficient and sufficient N-supply. New Phytol. 157: 65-81.

Larson, P.R. 1994. The vascular cambium: development and structure. Vol. 1. 1st ed. Springer Verlag, Berlin.

Murashige, T., and Skoog, F. 1962. A revised medium for rapid growth and bioassays with tobacco tissue cultures. Physiol. Plant. 15: 473-497.

Ortuno, M.F., Alarcon, J.J., Nicolas, E., and Torrecillas, A. 2004. Interpreting trunk diameter changes in young lemon trees under deficit irrigation. Plant Sci. 167: 275-280.

Raynal, D.J., Grime, J.P., and Boot, R. 1985. A new method for the experimental droughting of plants. Ann. Bot. 55: 893-897.

Robertson, A.J., Weninger, A., Wilen, R.W., Fu, P., and Gusta, L.V. 1994. Comparison of dehydrin gene expression and freezing tolerance in Bromus inermis and Secale cereale grown in con- trolled environments, hydroponics, and the field. Plant Physiol. 106: 1213-1216.

Rozenberg, P., Van Loo, J., Hannrup, B., and Grabner, M. 2002. Clonal variation of wood density record of cambium reaction to water deficit in Picea abies (L.) Karst. Ann. For. Sci. 59: 533 540.

Scholander, P.F., Hammel, H.T., Bradstreet, E.D., and Hemmingsen, E.A. 1965. Sap pressure in vascular plants. Science (Washington, D.C.), 148: 339-346.

Srebotnik, E., and Messner, K. 1994. A simple method that uses differential staining and light microscopy to assess the selectivity of wood delignification by white rot fungi. Appl. Environ. Microbiol. 60: 1383-1386.

Tardif, J., and Stevenson, D. 2001. Radial growth - climate association of Thuja occidentalis L. at the northwestern limit of its distribution, Manitoba, Canada. Dendrochronologia, 19: 179187.

Wimmer, R., Downes, G., and Evans, R. 2002. High-resolution analysis of radial growth and wood density in Eucalyptus nitens, grown under different irrigation regimes. Ann. For. Sci. 59: 519524.

Zahner, R. 1968. Water deficits and growth of trees. In Water deficits and plant growth. Edited by T.T. Kozlowski, Academic Press, New York. pp. 191-254.

Zahner, R., Lotan, J.E., and Baughman, W. 1964. Earlywood-latewood features of red pine grown under simulated drought and irrigation. For. Sci. 10: 361-370. 